\title{
Estimating population densities and biomass of ungulates in the temperate ecosystem of Bhutan
}

\author{
SONAM WANGYEL W AN G
}

\begin{abstract}
In this study I estimate population densities and biomass of the major prey species of tiger Panthera tigris, leopard Panthera pardus and dhole Cuon alpinus in Bhutan's temperate ecosystem and recommend measures for reducing crop damage whilst simultaneously protecting ungulate populations. Thirty-two transects totalling $849 \mathrm{~km}$ were walked to estimate densities and biomass of ungulates and primates in Bhutan's Jigme Singye Wangchuck National Park during 2005-2006. Adequate detections ( $>40$ sightings) for analysis using Distance were obtained for wild pig Sus scrofa $(\mathrm{n}=54)$, muntjac Munticus muntjac $(\mathrm{n}=102)$ and sambar Cervus unicolor $(\mathrm{n}=48)$. Because of similarity in morphology and habitat use, density of serow Capricornis sumatraensis was estimated using the detection probability for sambar. Detections for langur Trachypithecus geei and macaque Macca mulatta were combined $(\mathrm{n}=39)$ to estimate primate density. Mean estimated densities were 3.68 wild pig, 2.17 muntjac, 1.19 sambar, 2.37 primates and 0.36 serow $\mathrm{km}^{-2}$. The three primary prey species of large predators, wild pig, sambar and muntjac, provided a biomass of $379 \mathrm{~kg} \mathrm{~km}^{-2}$, which could support up to 1.2 tigers per $100 \mathrm{~km}^{2}$. However, the presence of other sympatric carnivores competing for prey in the same area suggests that the actual number of tigers that could be supported is lower. Livestock (density, $6.0 \mathrm{~km}^{-2}$; biomass, $615 \mathrm{~kg} \mathrm{~km}^{-2}$ ) apparently supplement prey availability. Ungulate density in the study area is generally low compared to other areas in the Indian sub-continent, and this may be due to conflicts with farmers, excessive grazing of livestock in the forest and the rugged terrain.
\end{abstract}

Keywords Bhutan, biomass, density, leopard, Panthera pardus, Panthera tigris, tiger, ungulates

\section{Introduction}

The inherent economic, aesthetic and food values of 1 ungulates and their ability to influence forest structure and composition, and dispersal of seeds, nutrient cycling, soil structure and succession (McNaughton, 1979; Crawley,

Sonam Wangyel Wang Nature Conservation Division, Department of Forests, Ministry of Agriculture, Thimphu, Bhutan. E-mail wangsonam@ gmail.com

Also at: National Zoological Park, Smithsonian Institution, Washington, DC, USA, and WildCRU, Oxford University, London, UK

Received 25 July 2008. Revision requested 17 September 2008.

Accepted 15 December 2008.
1983), make them an important component of any ecosystem in which they occur. For example, in Asia, ungulates such as the gaur Bos gaurus, sambar Cervus unicolor, chital Axis axis and wild pig Sus scrofa are known to provide 60$70 \%$ of biomass consumed by tigers Panthera tigris, leopards Panthera pardus and dholes Cuon alpinus (Johnsingh, 1992; Venkataraman et al., 1995).

Because ungulates form a major part of carnivore diets (Schaller, 1967; Seidensticker, 1976; Johnsingh, 1983; Karanth \& Sunquist, 1995; Karanth \& Nichols, 1998; Biswas \& Sankar, 2002; Bagchi et al., 2003; Jathanna et al., 2003) their conservation is essential for sustaining populations of predators. Declines in tiger populations have been attributed to low prey populations (Karanth \& Stith, 1999), and Schaller (1967), Sunquist (1981), Seidensticker \& McDougal (1993) and Karanth (1995) established correlations between tiger and prey densities. Karanth \& Sunquist (1995), Miquelle et al. (1996), Karanth \& Nichols (1998), Carbone \& Gittleman (2002) and Karanth et al. (2004) also proposed that abundance of carnivores is largely dependent on densities of a variety of sizes of ungulate prey and biomass. Tiger populations can thrive, even with low levels of poaching, if their prey base is protected and maintained at an adequate density (Karanth \& Stith, 1999).

If declining prey populations are a threat to the survival of predators then conservation strategies need to focus on protection of key prey populations. Although data on densities, biomass and distribution are thus important for monitoring prey populations (Karanth, 1995), their relatively low densities, unique habitat requirements, crop raiding habits, consumption by local people and lack of scientific studies hinders their conservation (Karanth \& Sunquist, 1992).

Several studies in the sub-tropical forests of Asia have estimated population parameters for ungulates in India (Schaller, 1967; Berwick, 1974; Johnsingh, 1983; Karanth \& Sunquist, 1992, 1995; Khan et al., 1996; Biswas \& Sankar, 2002; Bagchi et al., 2003; Jathanna et al., 2003), Sri Lanka (Eisenberg \& Lockhart, 1972) and Nepal (Seidensticker, 1976; Dinerstein, 1979; Tamang, 1982). However, these studies relied on non-standard methods and failed to address important questions relating to probabilities of detection and representative sampling (Karanth \& Sunquist, 1992; Buckland et al., 1993; Karanth \& Stith, 1999). After Karanth (1987) emphasized the importance of using statistically and biologically valid methods, only a few studies, in tropical India (Karanth \& Sunquist, 1992; Varman \& Sukumar, 1995; Khan et al., 1996; Karanth \& Nichols, 1998; Biswas \& Sankar, 2002; Jathanna et al., 2003), have generated estimates of herbivore densities based on distance sampling. Although 
these studies have advanced our understanding of ungulate ecology in tropical ecosystems in Asia, similar studies are required in the temperate forest ecosystems of Asia, especially in human-dominated landscapes.

Protected populations of wild ungulates sharing resources with livestock and herders in Bhutan's temperate forests provide an opportunity to evaluate ungulate population dynamics and their interaction with livestock and other anthropogenic factors. Such data, if obtained using established, robust methodology such as distance sampling (Eberhardt, 1978; Burnham et al., 1980; Buckland et al., 1993, 2001), can help formulate management strategies to protect predators and prey and reduce wildlife conflict with farmers. The study described here was designed to estimate population densities and biomass of the major prey species of tiger, leopard and dhole, and recommend measures for reducing crop damage whilst simultaneously protecting ungulate populations.

\section{Study area}

This study was conducted in five warden jurisdictions (Phobji, Athang, Langthel, Korphu and Trong) of the $1,750 \mathrm{~km}^{2}$ Jigme Singye Wangchuck National Park in central Bhutan (Fig. 1). The Park is bordered to the east and west, respectively, by the rivers Mangde chu and Sunkosh chu. The Park's diverse physical features, temperature and rainfall have created climatic zones ranging from wet sub-tropical in the south to permanent alpine pastures and glaciers in the north (Wang, 2001). Elevation rises from $150 \mathrm{~m}$ in Tingtibi, in the south, to $>4,900 \mathrm{~m}$ at the peak of Mt Jo-Durshing la. This steep altitudinal gradient makes c. $20 \%$ of the Park inaccessible for surveys, especially during summer and winter.

The Park has large areas of mature fir Abies spp. and pine Pinus spp. forests, ranging from sub-alpine to temperate, and large areas of climax broadleaf forest, ranging from temperate to subtropical. Along with Manas National Park in India and the Royal Manas National Park in Bhutan, this area is one of the largest tiger conservation areas in South Asia, includes the full range of vegetation types from the plains to the alpine zone, and has a high floral diversity. These diverse habitats host important populations of predators (tiger, leopard and dhole) and their prey (gaur, sambar, muntjac Munticus muntjac, wild pig, serow Capricornis sumatraensis, langur Trachypithecus geei and macaque Macaca mulatta). The Park is believed to be an important link between the northern and southern tiger populations of Bhutan, supporting up to $10 \%$ of Bhutan's total tiger population (Wang, 2001).

Almost 6,000 farmers live in 34 villages across the Park. Most of the farmers are either settled in the river valleys, on the gentle shoulders of the hills or in the glacier valleys. Agriculture (Wang et al., 2006) and livestock rearing
(Wang \& Macdonald, 2006) are the major sources of livelihood. Farmers residing at lower altitudes keep cattle, whereas farmers in alpine regions prefer yak.

\section{Methods}

Line transect methods (Eberhardt, 1978; Burnham et al., 1980; Buckland et al., 1993, 2001) were used to sight wild ungulates. Transects provide credible results (Anderson et al., 1979) and have been successfully used to estimate animal densities in south Asia (Karanth \& Sunquist, 1992, 1995; Varman \& Sukumar, 1995; Khan et al., 1996; Biswas \& Sankar, 2002; Bagchi et al., 2003; Jathanna et al., 2003). Thirty-two line transects (mean length $5.2 \mathrm{~km}$ ) were chosen to represent the five warden jurisdictions and different habitat types, elevations and proximity to waterholes and human settlements. The location and length of the transects were limited by accessibility on foot and by season. Field crews of 3-4 (usually but not always including SWW) walked the 32 transects 4-5 times each from September 2005 to July 2006 , covering a total length of $849 \mathrm{~km}$. Transects were mostly walked early in the morning (06.00-10.00) or in the evening (15.00-18.00) and animals were sighted on either sides of the transect line. All observers were appropriately trained in mammal observation and identification and distance sampling. For each transect total length walked, the number of animal clusters detected, cluster size, sighting distance (measured with a range finder) and sighting angle (measured with compass) were recorded for every prey species encountered. For species occurring in clusters (e.g. wild pigs and primates) the distances and angles were recorded to the centre of the cluster. Cattle populations occur in large clusters confined to certain areas and hence population estimation by the line transect method was inappropriate. Instead, cattle population data were obtained from village livestock officers.

Using software Distance v. 5.o (Thomas et al., 2006) analyses were carried out for each species in each of the warden jurisdictions. Data were checked for errors before importing into Distance (Jathanna et al., 2003). Prior to generating final results using Distance, exploratory analyses were carried out (Buckland et al., 2001) to check for any evidence of evasive movement before detection ('rounding' and 'heaping' of data) and to truncate outlier observations, if necessary, to improve model fitting (Jathanna et al., 2003). The fit of potential models to each data set was judged using Akaike's information criteria (AIC; Buckland et al., 2001). AIC was computed as AIC $=-2 \ln (k)+2 q$; where $\ln (k)$ is the $\log$ likelihood function evaluated as the maximum likelihood estimates of the model parameters and $q$ is the number of parameters in the model (Buckland et al., 1993, 2001; Burnham \& Anderson, 1998). The selected model was used in Distance to estimate the following model parameters: encounter rate $(\mathrm{n} / \mathrm{L} ; \mathrm{n}=$ number of detections, $\mathrm{L}=$ transect length), effective strip width, average probability of detection, cluster density, 

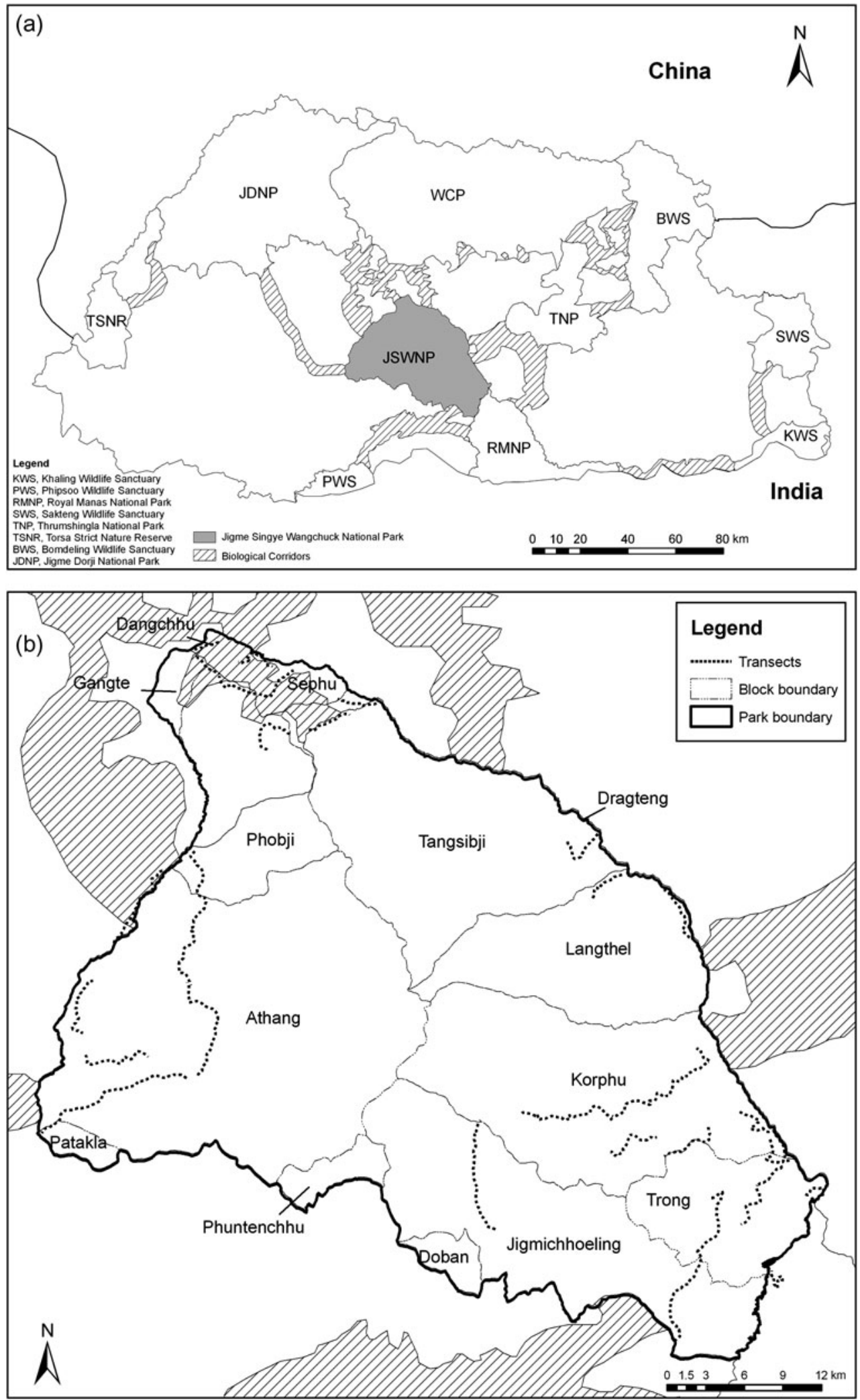

Fig. 1 (a) The locations of Jigme Singye Wangchuck National Park and the other protected areas of Bhutan and the biological corridors connecting them, and (b) the locations of the survey transects in the Park. 
cluster size and density of individuals (Burnham et al., 1980; Buckland et al., 1993). I used a global detection function with transect-wise encounter rates to obtain transect-wise density estimates, and used these estimates in an analysis of variance to test for differences in density estimates of prey species across the five areas. Density estimates and average body sizes of prey species obtained from the Field Guide to the Mammals of Bhutan (Royal Government of Bhutan, 2004) were then used to estimate the biomass of prey species in the study area.

\section{Results}

Along the $849 \mathrm{~km}$ of transects a total of 285 sightings were made of 13 species: muntjac $(n=102)$, wild pig $(n=54)$, sambar $(n=48)$, langurs $(n=24)$, macaque $(n=15)$, serow $(\mathrm{n}=6)$, goral Nemorhaedus goral $(\mathrm{n}=4)$, musk deer Moschus chrysogaster $(\mathrm{n}=1)$, Himalayan black bear Slenarctos thibetanus $(\mathrm{n}=2)$, Kalij pheasant Lophura leucomelanos melanota $(\mathrm{n}=12)$, hornbill Aceros nepalensis $(\mathrm{n}=9)$, white bellied heron Andrea insignis $(\mathrm{n}=7)$ and monal pheasant Lophorus impejenus $(\mathrm{n}=1)$. Preliminary analysis revealed low detection frequency and further analysis was therefore limited to prey species consumed by predators. Data for langur and macaque showed evidence of evasive movements before detection and 'heaping' of data (Table 1).

A half-normal key function with no adjustment terms best described the detection functions for muntjac, wild pig and sambar (Table 1). The estimated density of wild pig was the highest at $3.68 \mathrm{~km}^{-2}$. The estimated density of sambar, the preferred prey of tiger (Karanth \& Sunquist, 1995), was $1.19 \mathrm{~km}^{-2}$. Using the detection function for sambar, the density of serow was estimated to be 0.36 $\mathrm{km}^{-2}$. A half-normal key function also provided the best fit to the primate data $\left(2.37 \mathrm{~km}^{-2}\right)$. Estimates of density by warden jurisdiction describes the distribution of prey species in more detail (Fig. 2). Of the five areas, Trong had the highest overall prey density followed by Phobji and Langthel. Athang and Korphu had $<_{4}$ animals $\mathrm{km}^{-2}$. Muntjac, wild pig and sambar were sighted in all the five areas. Primate density was highest in Langthel followed by Korphu and Trong. Athang had low ungulate and primate densities. Analysis of variance revealed that the densities of ungulates $(F=17.66, \mathrm{P}<0.001)$ and primates $(F=11$, $\mathrm{P}<0.001$ ) were significantly different across the five areas.

Based on prey densities and average body sizes, the study area harboured a low ungulate biomass of $379 \mathrm{~kg} \mathrm{~km}^{-2}$. Muntjac (11\%) and sambar (43\%) together contributed $54 \%$ of the total biomass and wild pig $37 \%$. Based on the figures obtained from the records maintained by village livestock officers, livestock density was estimated to be $6 \mathrm{~km}^{-2}$, with a biomass of $615 \mathrm{~kg} \mathrm{~km}^{-2}$.

\section{Discussion}

Although distance sampling has been widely used (Biswas \& Sankar, 2002; Bagchi et al., 2003) for estimating prey densities and biomass (Karanth \& Sunquist, 1995; Karanth \& Nichols, 1998), its applicability has been limited in areas with low visibility such as Bhutan because of the need for an adequate number of sightings (Burnham et al., 1980; Buckland et al., 1993). The low detection probability in this study was because of Bhutan's mountainous terrain combined with low prey densities, occasional foggy weather and dry litter on the forest floor, the noise of which may have alerted animals before we were able to see them. In spite of these limitations, with sufficient effort distance sampling can be an effective tool in studying prey populations in Bhutan's difficult terrain.

The estimate of total ungulate density $\left(7.4 \mathrm{~km}^{-2}\right)$ is much lower than ungulate densities recorded in other areas in South Asia (Seidensticker, 1976; Dinerstein, 1979; Karanth \& Nichols, 1998; Biswas \& Sankar, 2002), which range from $16.3 \mathrm{~km}^{-2}$ (Karanth \& Sunquist, 1995) to $90.8 \mathrm{~km}^{-2}$ (Harihar, 2005). In addition to climatic and topographical factors, other possible reasons for the low densities in Bhutan may include poaching of ungulates, both for consumption and in retaliation for crop damage, and competition with local livestock. Local farmers put out snares and traps to protect their crops from wild ungulates and also graze livestock at a mean density of $6 \mathrm{~km}^{-2}$. Previous studies in India (Sankar, 1994; Mathai, 1999) have reported decreasing ungulate populations in areas with high competition from livestock.

TABLE 1 Results of distance sampling for three carnivore prey species and primates (langur Trachypithecus geei and macaque Macaca mulatta, combined) in Jigme Singye Wangchuck National Park, Bhutan (Fig. 1), with number of detections of each species or taxa, sampling effort in $\mathrm{km}$, Akiake information criteria (AIC), detection probability, mean cluster size and density and mean density of individuals (with $95 \%$ confidence interval, CI), and estimated biomass.

\begin{tabular}{lclllllll}
\hline Species & $\begin{array}{l}\text { No. of } \\
\text { detections }\end{array}$ & $\begin{array}{l}\text { Effort } \\
(\mathrm{km})\end{array}$ & AIC & $\begin{array}{l}\text { Detection } \\
\text { probability }\end{array}$ & $\begin{array}{l}\text { Cluster } \\
\text { size }\end{array}$ & $\begin{array}{l}\text { Cluster } \\
\text { density } \pm \text { SE }\end{array}$ & $\begin{array}{l}\text { Individual density } \pm \\
\text { SE }(95 \% \mathrm{CI})\end{array}$ & $\begin{array}{l}\text { Biomass } \\
\left.(\mathrm{kg} \mathrm{km})^{-2}\right)\end{array}$ \\
\hline Wild pig Sus scrofa & 54 & 678.2 & 437.45 & 0.33 & 37.2 & $0.91 \pm 0.27$ & $3.68 \pm 1.39(1.78-7.58)$ & 139.78 \\
Muntjac Munticus muntjac & 102 & 756.2 & 760.61 & 0.41 & 3.4 & $1.96 \pm 0.32$ & $2.17 \pm 0.36(1.55-3.03)$ & 43.35 \\
Sambar Cervus unicolor & 48 & 655.4 & 383.58 & 0.35 & 3.3 & $0.98 \pm 0.25$ & $1.19 \pm 0.31(0.71--1.98)$ & 163.06 \\
Primates & 59 & 516.3 & 238.43 & 0.49 & 11.0 & $0.28 \pm 0.01$ & $2.37 \pm 0.90(1.14-4.9)$ & 18.96 \\
\hline
\end{tabular}




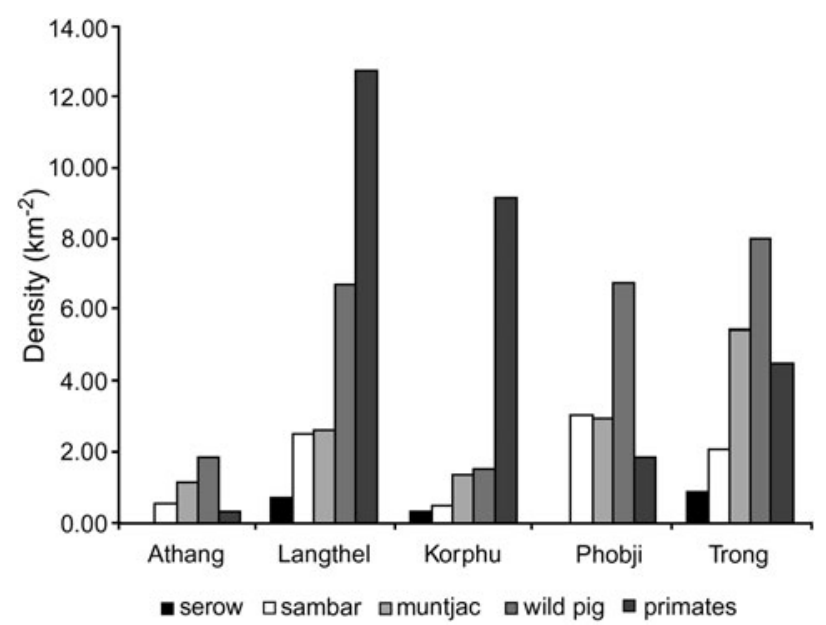

FIG. 2 Density of the five main prey species in five warden jurisdictions in Jigme Singye Wanghcuck National Park (Fig. 1).

Voluntary resettlement of residents and their stock from the Nagarahole (Karanth \& Sunquist, 1992) and Gir (Khan, 1996) protected areas in India allowed prey populations to increase. Long-term temporal and spatial monitoring of ungulate populations, in habitats both with and without cattle grazing and human pressures, are required to elucidate the factors limiting ungulate populations in Bhutan.

The estimated density of wild pigs in Bhutan $\left(3.7 \mathrm{~km}^{-2}\right)$ is similar to densities reported for other areas in Asia, ranging from $2.5 \mathrm{~km}^{-2}$ in Kanha, India (Karanth \& Nichols, 1998) to $6.1 \mathrm{~km}^{-2}$ in the Chilla Range, India (Harihar, 2005). Wild pigs were often sighted because they frequent open marshy areas where visibility is high, whereas other ungulate species are less easily sighted because of thick forest cover. Muntjac and sambar are also widely distributed across the study area. The muntjac density of $2.2 \mathrm{~km}^{-2}$ is lower than in Kanha and Nagarhole, India $\left(6.0 \mathrm{~km}^{-2}\right.$; Karanth \& Nichols, 1998), but higher than in Bandipur, India, (1.0 km ${ }^{-2}$; Johnsingh, 1983) and Bardia, Nepal $\left(1.7 \mathrm{~km}^{-2}\right.$; Dinerstein, 1980). The density of sambar $\left(1.2 \mathrm{~km}^{-2}\right)$, mostly sighted in hilly areas, is similar to that reported from Kanha $\left(1.5 \mathrm{~km}^{-2}\right.$; Karanth \& Nichols, 1998). The highest density of sambar is reported from the Chilla Range $\left(24.3 \mathrm{~km}^{-2}\right.$; Harihar, 2005).

Ungulate biomass in Bhutan is the lowest reported from studies in Asia $\left(379 \mathrm{~kg} \mathrm{~km}^{-2}\right)$. The lowest biomass reported previously was in Bardia National Park $\left(2,842 \mathrm{~kg} \mathrm{~km}^{-2}\right.$; Dinerstein, 1979). Large mammalian predators such as tigers and leopards have been known to respond to prey biomass and densities (Carbone \& Gittleman, 2002; Karanth et al., 2004). In Bhutan low ungulate densities may be responsible for low numbers of predators (Wang, 2008). Given an annual prey intake of c. 3,000 kg per tiger (Karanth \& Nichols, 1998), a biomass of $379 \mathrm{~kg} \mathrm{~km}^{-2}$ could support only up to 1.2 tigers per $100 \mathrm{~km}^{-2}$. If we consider other predators such as leopards and dholes, which also share this ungulate biomass, then the population of tigers that could be supported is even lower.

To maintain viable predator populations and reduce predation on livestock, wild prey densities need to increase. Firstly, resource competition between livestock and wild ungulates needs to be reduced by reduction in grazing pressure of domestic livestock in the forests. Secondly, livestock populations need to be reduced in the forests so that wild ungulates may recolonize their natural habitats away from human settlements. However, livestock currently provides a major proportion of predator diets, especially for tigers and leopards (Wang \& Macdonald, 2009). Any abrupt reductions in livestock could lead to food scarcity for predators. Habitat management could attract native ungulates into forests from marginal lands near settlements and then a programme could be initiated to reduce livestock grazing pressure. A livestock intensification programme to reduce livestock numbers, and in particular stray grazing in forest, is now being implemented across national parks in Bhutan. If this proves successful, managers could gradually ban grazing in areas of high ungulate density and biomass. This would provide multiple benefits to conservation: reduction in crop damage, lower predation rates on livestock and, potentially, improved support amongst farmers for conservation of large carnivores. Where such programmes are in place the frequency of crop damage is declining, and wild ungulates are being sighted more frequently in the forest.

\section{Acknowledgements}

I would like to thank my field assistants (Kinzang Lham, Kuenzang Dorji, Kesang Wangchuk, Sonam Dorji, K.B. Gurung, Jigme Wangchuk, Karma and Ngawang Tenzin) for their hard work, and Drs James P. Lassoie, Paul Curtis, Milo E. Richmond, Ullas Karanth, A.J.T. Johnsingh and Koustubh Sharma for reviewing this article. I greatly appreciate the financial support of Save the Tiger Fund/ NFWF, Whitley Fund for Nature and Disney Conservation.

\section{References}

Anderson, D.R., LaAke, J.L., Crain, B.R. \& Burnham, K.P. (1979) Guidelines for the transect sampling of biological populations. Journal of Wildlife Management, 43, 70-78.

Bagchi, S., Goyal, S.P. \& SAnkar, K. (2003) Prey abundance and prey selection by tigers (Panthera tigris) in a semi-arid, dry deciduous forest in western India. Journal of Zoology, 260, 285-290.

Berwick, S. (1974) The Gir Forest: an endangered ecosystem. American Scientist, 64, 28-40. 
Biswas, S. \& SAnkar, K. (2002) Prey abundance and food habit of tigers (Panthera tigris tigris) in Pench National Park, Madhya Pradesh, India. Journal of Zoology, 256, 411-420.

Buckland, S.T., Anderson, D.R., Burnham, K.P. \& LaAke, J.L. (1993) Distance Sampling: Estimating Abundance of Biological Populations. Chapman and Hall, New York, USA.

Buckland, S.T., Anderson, D.R., Burnham, K.P. \& LaAke, J.L. (2001) Introduction to Distance Sampling: Estimating Abundance of Biological Populations. Oxford University Press, Oxford, UK.

Burnham, K.P. \& Anderson, D.J. (1998) Model Selection and Inference: A Practical Information-Theoretic Approach. SpringerVerlag, New York, USA.

Burnham, K.P., Anderson, D.J. \& LaAke, J.L. (1980) Estimation of Density from Line Transect Sampling of Biological Populations. Wildlife Monograph. The Wildlife Society, Bethesda, USA.

Carbone, C. \& Gittleman, J.L. (2002) A common rule for scaling of carnivore density. Science, 295, 2273-2276.

Crawley, M.J. (1983) Herbivory: The Dynamics of Animal-Plant Interactions. University of California Press, Berkeley, USA.

Dinerstein, E. (1979) An ecological survey of the Royal KarnaliBardia Wildlife Reserve, Nepal. Part 2: Habitat/animal interactions. Biological Conservation, 16, 265-300.

Dinerstein, E. (1980) An ecological survey of the Royal KarnaliBardia Wildlife Reserve, Nepal. Part 3: Ungulate populations. Biological Conservation, 18, 5-37.

EBerhardt, L.L. (1978) Transect methods for population studies. Journal of Wildlife Management, 42, 1-31.

Eisenberg, J.F. \& Lockhart, M. (1972) An ecological reconnaissance of Wilpattu National Park, Ceylon. Smithsonian Contributions to Zoology, 101, 1-118.

Harihar, A. (2005) Population, food habitats and prey densities of tiger in Chilla Range, Rajaji National Park, Uttaranchal, India. MSc thesis, Saurashtra University, Gujarat, India.

Jathanna, D. (2001) Density, biomass and habitat occupancy of ungulates in Bahdra Tiger Reserve, Karnataka. MSc thesis, Saurashtra University, Gujarat, India.

Jathanna, D., Karanth, K.U. \& Johnsingh, A.J.T. (2003) Estimation of large herbivore densities in the tropical forests of southern India using distance sampling. Journal of Zoology, 261, 285-290.

Johnsingh, A.J.T. (1983) Large mammalian prey-predators in Bandipur. Journal of the Bombay Natural History Society, 80, 1-57.

Johnsingh, A.J.T. (1992) Prey selection in three large sympatric carnivores in Bandipur. Mammalia, 56, 517-526.

Karanth, K.U. (1987) Analysis of predator-prey balance in Bandipur Tiger Reserve with reference to census reports. Journal of the Bombay Natural History Society, 85, 1-8.

Karanth, K.U. (1995) Estimating tiger Panther tigris populations from camera trapping data using capture-recapture models. Biological Conservation, 71, 333-338.

KaRANTH, K.U. \& Nichols, J.D. (1998) Estimation of tiger densities using photographic captures and recaptures. Ecology, 79, 28522862.

Karanth, K.U., Nichols, J.D., Kumar, N.S., Link, W.A. \& Hines, J.E. (2004) Tigers and their prey: predicting carnivore densities from prey abundance. Proceedings of the National Academy of Sciences of the USA, 101, 4854-4858.

Karanth, K.U. \& S Tith, B.M. (1999) Prey depletion as a critical determinant of tiger densities. In Riding the Tiger: Tiger Conservation in Human-dominated Landscapes (eds J. Seidensticker, S. Christie \& P. Jackson), pp. 100-113. Cambridge University Press, Cambridge, UK.

Karanth, K.U. \& Sunquist, M.E. (1992) Population structure, density and biomass of large herbivores in the tropical forests of Nagarhole, India. Journal of Tropical Ecology, $8,21-35$.

Karanth, K.U. \& Sunquist, M.E. (1995) Prey selection by tiger, leopard and dhole in tropical forests. Journal of Animal Ecology, 64, 439-450.

KHAN, J.A. (1996) Factors governing the habitat occupancy of ungulates in Gir Lions Sanctuary, Gujarat, India. International Journal of Ecology and Environmental Science, 22, $73-83$.

Khan, J.A., Chellam, R., Rodgers, W.A. \& Johnsingh, A.J.T. (1996) Ungulate densities and biomass in tropical deciduous forests in Gir, Gujarat, India. Journal of Tropical Ecology, 12, 149-162.

M атна, M. (1999) Habitat occupancy across anthropogenic disturbances by sympatric ungulate species in Panna Tiger Reserve. MSc thesis, Saurashtra University, Rajkok, India.

McNaughton, S.J. (1979) Grassland-herbivore dynamics. In Serengeti: Dynamics of an Ecosystem (eds A.R.S. Sinclair \& M. Norton-Griffiths), pp. 46-81. Chicago University Press, Chicago, USA.

Miquelle, D.G., Smirnov, E.N., Quigley, H.G., Hornocker, M.G., Nikalaev, I.G. \& Matyushin, E.N. (1996) Food habits of Amur tigers in Sikhote-Alin Zapovednik and the Russian Far East and the implications for conservation. Journal of Wildlife Research, 1, 138-147.

Royal Government of Bhutan (2004) Field Guide to the Mammals of Bhutan. Royal Government of Bhutan, Thimphu, Bhutan.

S ANKAR, K. (1994) The ecology of three large sympatric herbivores (chital, sambar and nilgai) with special reference for reserve management in Sariska Tiger Reserve, Rajasthan. $\mathrm{PhD}$ thesis, University of Rajasthan, Jaipur, India.

Schaller, G.B. (1967) The Deer and the Tiger. University of Chicago Press, Chicago, USA.

Seidensticker, J. (1976) Ungulate populations in Chitwan Valley, Nepal. Biological Conservation, 10, 183-210.

Seidensticker, J. \& McDougal, C. (1993) Tiger predatory behavior, ecology and conservation. In Mammals as Predators (eds N. Dunstone \& N.L. Gorman), pp. 105-125. Clarendon Press, Oxford, UK.

SUNQUIST, M.E. (1981) The social organization of tigers (Panthera tigris) in Royal Chitwan National Park, Nepal. Smithsonian Contributions to Zoology, 336, 1-98.

TAMANG, K.M. (1982) The status of tiger (Panthera tigris) and its impact on principal prey populations in the Royal Chitwan National Park, Nepal. PhD thesis, Michigan State University, East Lansing, USA.

Thomas, L., Laake, J.L., StrindberG, S., Marques, F.F.C., Buckland, S.T., Borchers, D.L. et al. (2006) Distance v. 5.o. Research Unit for Wildlife Population Assessment, University of St. Andrews, UK. Http://www.ruwpa.st-and.ac.uk/distance/ [accessed 2 July 2009].

VARMAn, K.S. \& SUKUmar, R. (1995) The line transect method for estimating densities of large mammals in a tropical deciduous forest: an evaluation of modes and field experiments. Journal of Bioscience, 20, 273-287.

Venkataraman, A.B., Arumugam, R. \& Sukumar, R. (1995) The foraging ecology of dhole (Cuon alpinus) in Mudumalai Sanctuary, Southern India. Journal of Zoology, 237, $543-561$

W ANG, S.W. (2001) Conservation Management Plan for the Black Mountains National Park. Nature Conservation Division, Ministry of Agriculture, Thimphu, Bhutan.

W ANG, S.W. (2008) Understanding ecological interactions among carnivores, ungulates and farmers in Bhutan's Jigme Singye 
Wangchuck National Park. PhD thesis, Cornell University, Ithaca, USA.

Wang, S.W., Curtis, P. \& Lassoie, J.P. (2006) Farmer perceptions of crop damage by wildlife in Jigme Singye Wangchuck National Park, Bhutan. Wildlife Society Bulletin, 34, 359-365.

WANG, S.W. \& Macdonald, D.W. (2006) Livestock predation by carnivores in Jigme Singye Wangchuck National Park, Bhutan. Biological Conservation, 129, 558-565.

WANG, S.W. \& MACDONALD, D.W. (2009) Feeding habits and niche partitioning in a predator guild composed of tigers, leopards and dholes in a temperate ecosystem in central Bhutan. Journal of Zoology, 227, 275-283.

\section{Biographical sketch}

SONAM WANGYEL WANG's research interests include understanding the relationships between predators, prey and people in the mountainous region of Bhutan, with a particular focus on the ecology of tigers and leopards. He is currently using camera-trapping and distance sampling to estimate populations of tigers, leopards and their prey species in Bhutan's rugged terrain. 